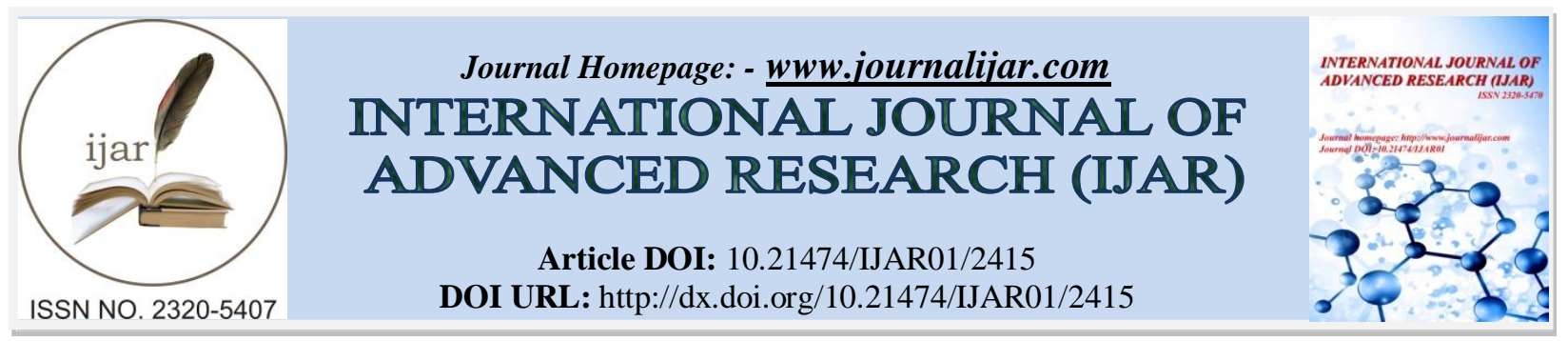

RESEARCH ARTICLE

\title{
INVESTIGATION OF THE ORIENTATION IN ACCOUNTING ETHICAL PRACTICES IN GOVERNMENT MINISTRIES IN TANZANIA.
}

Erick Mtandi ${ }^{1}$ and Bukaza Chachage ${ }^{2}$.

Open University of Tanzania, 2Open University of Tanzania.

\section{Manuscript Info}

Manuscript History

Received: 20 October 2016

Final Accepted: 22 November 2016

Published: December 2016

Key words:-

Accounting ethics, Unethical

accounting, ethical practices

\section{Abstract}

Unethical accounting practices have been teasing the United Republic of Tanzania for years; as such the Country has ever been experiencing difficulties in managing its public financial resources which could have been used to provide quality and adequate social services to majority of Tanzanians. Frequently, international and national reports have pointed out the existence of the problem in public entities. The major objective of this study was to investigate the orientation in accounting ethical practices in government ministries in Tanzania. Specifically, the study examined the influence of the perception of accountants on their role to the public on ethical practices, the influence the perception of accountants on their professional code of conduct on ethical practices, the influence of political pressure on accountants' ethical practices and the influence the perception of accountants on their ethical orientation on accountants' ethical practices. Methodologically, the study was qualitative influenced sequentially conducted to validate quantitative findings, and data were collected using in-depth interviews. The study involved a sample of 12 auditors purposively selected from the National Audit Office in Tanzania (NAOT) and the big four auditing firms. The data were analyzed qualitatively using content analysis approach whereby themes were coded and the results from the interview were recorded. The reliability of the study showed reproduction of the responses while the validity of the study was confirmed by facts whereby wide spread scandals of Richmond, BOT twin towers; EPA and Tegeta ESCROW Account were given as examples. The qualitative study was sequentially conducted to validate the empirical findings that were earlier obtained in quantitative study. The empirical findings from qualitative study, confirmed the quantitative results that the accountants' role to the public and the accountants' professional code of conduct do not influence ethical practices. They also confirmed that pressure from politicians and ethical orientation of individual accountants can influence the accountant's ethical practices. However, the findings also indicated that unethical accounting practices may be caused by public services environment which allows the following vices: society evil expectation, political based appointments, confusing chain of command, corruption triangle, weak oversight bodies, weak internal controls, unpunished culprits and failure to 
uphold religious values; discriminative motivation, misbehaving leaders, poverty background and Selfishness. The study recommended the installation of better working environment in public entities which may, allow accountants to undergo post education professional orientation, curtail the political pressure and vices of the accounting ethics.

Copy Right, IJAR, 2016,. All rights reserved.

\section{Introduction:-}

The Government of Tanzania has been experiencing difficulties and problems in managing public resources including financial resources in most Ministries, Independent Departments and Agencies (MDAs) (Policy forum, 2012; Controller and Auditor General (CAG), 2015). Many public MDAs have suffered losses of millions of shillings due to mismanagement of funds through unethical accounting systems and processes (Lynchs, 2005). Likewise, the Chief Auditor General (CAG) expressed qualification opinions, which indicated material misstatement in the financial statements in the audit reports for the years 2011-12, 2012-13, 2013-14 and 2014-15 due to misuse of substantial public funds and deliberate improper accounting practices in some of the items (CAG, 2015). Despite the presence of various accounting related legal instruments to guide their practices such as URT Constitution (1977), the Public Procurement Act (URT, 2004), the Public Finance Act (URT, 2001), Leadership Code of Ethics (URT, 1995), PCCB (URT, 2007), Judiciary and Police Force, and the National Board of Accountants and Auditors (NBAA), accountants' ethical practices are questionable due to the reported mismanagement of public financial resources. In short, these instruments require that every professional accountant observes the principle of integrity, objectivity, ethical practices, competence and confidentiality. Violation of accounting ethics in Tanzania has been a topical issue for quite some time; For instance, Kashonda (2011) posits that the recording of financial transaction is one such activity that may, if unethically done, disturb the relationship between individuals and communities and distort the fairness of value transfers between parties to transactions. Furthermore, Kashonda (2011) correctly observes that false accounting entail creative accounting and misleading financial reports. Chanyika (2011) in TAA professional accountant Journal concurs with Kashonda (2011) when he observed false and altered disbursement documents in some local governments and in one of district Hospitals in Tanzania. He exposes the following issues that have commonly been faced by fraud examiners when detecting false documents in the organization's disbursement records; use of simple cash receipts or invoices, fictitious expenses, overstated travel expenses and use of generic forms which have many irregularities.

Violation of accounting ethics in Tanzania has also been reported in various reports (Afro Barometer, 2006; Babeiya, 2011).The reports posit that Tanzania suffers from widespread corruption at all levels in the Government and that the Government's internal control systems were inadequate, or was insufficiently enforced, to prevent abuses. Afro Barometer (2006) reveals corruption among public servants. In the Journal of politics and law, Babeiya (2011) also posits existence of corruption among public servants. He says that the main implementation challenge to anti-corruption initiatives is the fact that the war against corruption in Tanzania is led by the commanders who are consciously objectors.

Mismanagement of funds has also been reported by Corruption Tracker System (CTS) (2011). The system argues for the existence of misappropriation of funds and corruption in Tanzanian government ministries. It shows the magnitude of the problem in public entities whereby, for example Norwegian Kroner 300,000 was misappropriated, causing Norway to stop funding those forest climate projects. The money was an aid to Ministry of Natural Resources and Tourism (MNRT) for forest protection. The existence of corruption among public servants and misappropriation of funds as evidenced above indicates the availability of unethical practices in the accounting processes and systems in Tanzania. This study therefore sought to investigate the prevalence of unethical accounting practices in Ministries of the United Republic of Tanzania who are recipients of the parliamentary appropriated budget. Prevalence of unethical accounting practices has caused loss of millions of Tanzania shillings including donor funds (CTS, 2011). The rampant scandals of grand corruption such as Richmond, BOT-EPA, BOT Twin Towers and Tegeta Escrow Account suggest the dynamics of the problem (AfriMAP, 2015).

\section{Objectives:-}

The general objective of the study was to investigate the orientation in accounting ethical practices in government ministries in Tanzania in order to recommend specific considerations for motivating ethical practices amongst 
accountants and eventually mitigate the mismanagement of public financial resources in Tanzania. The study addressed the following specific objectives:

- To examine the influence of accountants' role to the public on ethical practices

- To evaluate the influence of accountants' professional code of conduct on ethical practices

- To assess the influence of political pressure on accountants' ethical practices

- To check out the influence of accountants' ethical orientation on accountants' ethical practices

Research questions:-

To address the specific objectives, the study tested the following research questions:

- Does the perception of accountants towards their role to the public have a positive influence on their ethical practices?

- Does the perception of accountants towards their professional code of conduct have a positive influence on their ethical practices?

- Does the political pressure have negative influence on the accountants' ethical practices?

- Does the perception of accountants towards their ethical orientation have a positive influence on the accountants' ethical practices?

\section{Methodological consideration:-}

The area of the qualitative study was the auditing firms which included Core Security Limited, KPMG, PWC, Ernst \& Young and National Audit Office in Tanzania (NAOT). The firms were selected purposively on the understanding that they are the ones often got involved in testing the orientation in accounting ethical practices when auditing public accounts. The sampling techniques according to Saunders et al. (2009) can be probabilistic or nonprobabilistic. The study used a non-probabilistic sampling technique whereby 12 auditors were purposively selected to participate in the in-depth interviews. The purposive selection was employed because of the homogeneity of the auditors in terms of their professionalism and involvement in testing ethical orientation. These auditors included Managing Partners, Controller and Auditor General, NAOT Executive heads of divisions and NAOT Assistant Auditors general. The distribution of the sample was: Core Securities Limited 1, KPMG 1, PWC 1, Ernst \& Young 1, CAG 1, NAOT Executive heads of divisions 3 and NAOT Assistant Auditors general 4. The data were collected through interviews and they were analyzed using content analysis based on thematic objectives. Before the data were collected, the researchers asked permission through mailed letters and telephones to respective auditing firms. Interviews were conducted by both face to face and emails, dependent on the choice of the respondent. Irrespective of their email choices, 4 auditors kept quiet; that means only 8 auditors, representing 67 percent, participated the interviews.

\section{Findings:- \\ Reliability and validity:-}

According to Morse et al. (2002), reliability in qualitative study can be measured by observing criteria of credibility, transferability and confirm ability. In this study, the findings indicated that the information obtained was credible in the sense that they captured what is really happening in Tanzania, the results are transferable as they can be inferred to all public entities everywhere and they are confirmable as the interviewees reproduced the responses. On the part of validity which can be tested by either truth, actuality, evidence, objectivity, facts, reasons, university laws or mathematical data, the study tested it by facts whereby most auditors gave examples of the unethical accounting scandals recently rung in the ears of Tanzanians. The validity test indicated that unethical accounting practices exist in the country. To cement the fact, most auditors gave example of the wide spread scandals of Richmond, BOT Twin towers, EPA account and Tegeta ESCROW Account. The reliability test indicated that most auditors reproduced the responses (confirm ability).

\section{Answers to research questions:-}

Research questions reflected thematic objectives and the results are presented below. Firstly, it was asked that:

Q1: Does the perception of accountants towards their role to the public have a positive influence on ethical practices?

Many auditors indicated that the perception of accountants towards their role to the public does not help accountants to practice ethically. Very few auditors argued that if accountants are provided with continued training on their role to the public, they can practice ethically. The result was consistent with what was found in quantitative study which 
indicated that perception of accountants on their role to the public insignificantly affects the way they behave (Mtandi et al., 2016). As matter of evidence, auditor UL said:

"Perception of accountants on their role to the public does not help, because of the culture of the society to encourage unethical behaviour by expecting whoever holds a public position to change drastically (steal and own properties)and that if he/she doesn't is regarded as a foolish one - the society get surprised. Such society evil expectation encourages all public organs including police force (law enforcers) to be corrupt. Accountants as well are influenced by the society to act unethically. The example of the ethical leader who is blamed to date is the father of the nation Mwl. Julius Kambarage Nyerere. He did not submit to the influence of the society" (UL).

Secondly, it was asked that:

Q2: Does the perception of accountants towards their professional code of conduct have a positive influence on ethical practices?

Most auditors said that there is no relationship between the two. Very few auditors said that if accountants in government ministries understand their professional code of conduct (which include integrity, confidentiality, objectivity, competence, ethics and professional due care) may practice ethically. The result was consistent with the quantitative findings which indicated that accountants' perception towards their professional code of conduct insignificantly affects the way they behave (Mtandi et al., 2016). In the below quoted explanations, auditor PA supports the conclusion:

"No, unethical accounting practices in government ministries in Tanzania are not caused by ignorance of accountants on their professional code of conduct, because both the knowledgeable and the less knowledgeable act equally. According to what I know unethical accounting practices are caused by worst system of justification to steal. That, when the small see those expected to exhibit ethics steal, they also decided to cheat and steal. The big steal the small steal as well. The big are those holding political positions. The example here is that, when an auditor reveals malpractice the concerned person can try to bribe him and if he refuses, his life is jeopardized and the concerned may decide to go higher for the same bribe motive so as to conceal the malpractice. It is our system which needs to change because it is a corrupt one".

Thirdly, it was asked that:

Q3: Does the political pressure negatively influence the accountants' ethical practices?

Under this thematic content variable, all auditors said that, pressure from political leaders influences ethical practices of accountants. The result was consistent with the empirical findings which indicated that pressure from politicians influences the accountant's ethical practices (Mtandi et al., 2016). Auditor BB evidences the concluded result with his below quoted explanations:

"Accounting ethics in government ministries is a small part of the general behaviour of public officials. You cannot discuss behaviour of public accountants alone without touching the behaviour of all public officials which include politicians and technical. To me, all public officials have left aside the issue of ethics in order that they can benefit themselves and their families. You can recall scandals like those of EPA, BOT TWIN TOWERS AND TEGETA ESCROW. Not only accountants who got involved and of course they are seldom mentioned but also politicians and other respected lawyers. All these happened because people in public service are infected by the vice known as selfishness - to satisfy their stomachs. So, my brother people are selfish. They consider themselves. So we shouldn't point fingers to accountants alone but to all entrusted in public service. So, knowledge ability of accountants on their role to the public and on their professional code of conduct does not help to instil ethical practices in this country, unless if the whole system is revamped. So, the worst situation which has ever been reported by auditors and various researchers is not caused by accountants only but by all who are exposed to theft loopholes".

Lastly, it was asked that:

Q4: Does the perception of accountants towards their ethical orientation have a positive influence on the accountants' ethical practices? 
On this thematic variable which encompassed ethical theories of justice, deontology, relativism and utilitarianism, most auditors also accepted the relationship between perception of accountants towards their ethical orientation and accountants ethical practices. The result again is consistent with the quantitative findings which indicated that accountants' ethical orientation influences ethical practices (Mtandi et al., 2016). Response from auditor DT said:

"Well. Let us first define what is accounting ethics? Accounting ethics are moral principles which govern the accountancy profession. It is true that there have been unethical accounting practices in Tanzania. This is not a myth but various reports by professionals have shown the practices. Yes, on one part ignorance on ethical orientation causes the malpractice but on the other part those charged with corporate governance have been the causes. When I say those charged with corporate governance, I mean; political leaders and respective accounting officers which include permanent secretaries, executive directors and regional commissioners".

\section{Conclusions and Recommendations:-}

The general purpose of this study was to investigate the orientation in accounting ethical practices in government ministries in Tanzania in order to recommend ways to mitigate the mismanagement of public funds in Tanzania. On the issue of public role, the findings indicated that there is no relationship between the perception of accountants on their role to the public and their ethical practices. The result suggests that the knowledge of accountants about their role to the public does not affect ethical practices in Tanzania. With regard to the professional code of conduct and ethics, the findings indicated that there is no relationship between the accountants' perception towards their professional code of conduct and ethical practices. The result suggests that the knowledge of accountants about their professional code of conduct does not affect ethical practices in Tanzania. This finding differs from the findings by Gilman (2005) who reported that knowledge of the ethics codes and codes of conduct were essential ingredients in the prevention of the unethical practices such as corruptions. With regard to the accountants' ethical orientation, the finding indicated that ethical orientation affects positively ethical practice in Tanzania. The findings are consistent with the findings by Uyar and Ozer (2011) and Emerson et al. (2007) who reported that ethical orientation affects ethical professional commitment positively. With regard to political pressure, which exists in most public entities, the findings indicated that there is negative relationship between political pressure and ethical practices. The result suggests that the existence of political pressure affects the ethical practices in Tanzania negatively. The study recommends that the accountants should acquire the knowledge and practice of ethical theories by regularly attending to the continuing ethical educations and trainings; environment with an incentive effect is created in the government organizations to curtail the political pressure towards accountants from the politicians. The study also recommends that even though the role to the public and awareness of the code of ethics did not have any significant effect to ethical practices, it is important that the accountants take a proactive measure by considering these variables seriously in their operations.

\section{References:-}

1. AfriMap (2015), Effectiveness of Anti-Corruption Agencies in East Africa, New York NY, African Minds publisher

2. Barometer, Afro (2006), Combating Corruption in Tanzania: Perspective \& Experience, Dar es Salaam, Tanzania.

3. Babeiya, E. (2011), "Electoral Corruption and the Politics of Elections Financing in Tanzania", Journal of Politics and Law, Vol. 4, No. 2, September, 2011.

4. CAG, (2015), Annual Audit Report, Government Printer, Dar es Salam, Tanzania.

5. Chanyika, Y.M. (2011), "False or Altered Disbursement Documents", TAA Professional Accountant Journal, Vol. 23, No. 1, January-June, 2011.

6. CTS (2011), Corruption in Tanzania, Retrieved from the World Wide Web at [http://www.corruptiontracker.or.tz/tcts/] on $28^{\text {th }}$ June, 2013

7. Emerson, T.L.N., Conroy, S. and Stanley, C. (2007), "Ethical Attitudes of Accountants: Recent Evidence from a Practitioners' Survey", Journal of Business Ethics, Vol. 71, Vol. 73-87.

8. Gilman, S. (2005), Ethics Codes and Codes of Conduct as Tools for Promoting an Ethical and Professional Public Service, Worshington DC, USA, World Bank.

9. Kashonda, M.A. (2011), "Effects of Unethical Recording of Financial Transactions", TAA Professional Accountant Journal, Vol. 23, No. 1, January-June, 2011.

10. Lynchs, F. (2005), Advanced Corporate Reporting (International Stream), The Financial Training Company Ltd (FTC). William Clowes Ltd, Beccles, Suffolk, Great Britain. 
11. Morse, J. M., Barrett, M., Mayan, M., Olson, K., \&Spiers, J. (2002).Verification Strategies for Establishing Reliability and Validity in Qualitative Research.International Journal of Qualitative Methods, vol. 1, no.2

12. Mtandi, E., Chachage, B. and Malima, G. (2016): An Investigation of the Dynamics of Unethical Accounting Practices in the Government Organizations in Tanzania. ANVESHAK INTERNATIONAL JOURNAL OF MANAGEMENT (AIJM), Vol. 5, No. 1

13. Policy Forum (2012), General Budget Support: Are Donors Abandoning Tanzania? Retrieved from the World Wide Web at [http://www.policyforum-tz.org/sites/default/files/DonorMoneyinthebudget.pdf] on $23^{\text {rd }}$ July, 2014

14. Saunders, M., Lewis, P. and Thornhill, A. (2009), Research Methods for Business Students, ( ${ }^{\text {th }}$ edn.), Pearson Education Limited, Harlow, England.

15. URT, (1977), Constitution of the United Republic of Tanzania, Government printer, Dar es salaam, Tanzania

16. URT, (1995), The Public Leadership Code of Ethics 1995, Government printer, Dar es salaam, Tanzania

17. URT, (2001), The Public Finance Act 2001, Government printer, Dar es salaam, Tanzania

18. URT, (2004), The Public Procurement Act 2004, Government printer, Dar es salaam, Tanzania

19. URT, (2007), The Prevention and Combating Corruption Bureax Act 2007, Government printer, Dar es salaam, Tanzania

20. Uyar, M. and Ozer, G. (2011), "The Ethical Orientation and Professional Commitment: An Empirical Examination on Turkish Accountants",African Journal of Business Management, Vol. 5, No. 23. 